\title{
PROGRAMMABLE LOGIC DEVICES AS A TOOL IN STRUCTURE'S DAMAGE DETECTION APPLICATIONS
}

\begin{abstract}
SUMMARY
Programmable logic devices is one of the most dynamically developing fields of technology today. It is widely used in many kinds of signal acquisition as well as data processing systems mainly because of it's large flexibility and continuously growing abilities. It gives a designer a powerful tool, which allows for the creation of almost any kind of logic topology and any kind of data processing system, which additionally may be freely reprogrammable without any physical changes in the platform device. This paper briefly describes programmable devices technology contribution in the development of various SHM (System Health Monitoring) systems. The SHM systems mentioned in this paper have already been designed, built and successfully tested on real structures.
\end{abstract}

Keywords: modal filter, damage detection, programmable logic devices, data processing

\section{PROGRAMOWALNE URZĄDZENIA LOGICZNE JAKO NARZĘDZIE W WYKRYWANIU USZKODZEŃ}

Programowalne urządzenia logiczne to jedno z najprężniej rozwijających się obecnie dziedzin technologii. Sa szeroko stosowane w wielu rodzajach układów akwizycji czy przetwarzania danych, głównie z uwagi na swa elastyczność i ciagle wzrastajace możliwości. Daja projektantowi narzędzie, które pozwala tworzyć dowolna topologię logicznego układu przetwarzania danych. Dodatkowym atutem jest dowolna możliwość przeprogramowania ich bez konieczności fizycznej zmiany konfiguracji układu. Ten artykuł opisuje zastosowanie wspomnianej technologii do budowy układów zwiazanych $z$ monitorowaniem stanu obiektów. Pokazane w pracy uklady zostały zaprojektowane, wykonane i przetestowane na obiektach technicznych.

Slowa kluczowe: filtr modalny, wykrywanie uszkodzeń, programowalne urzadzenia logiczne, przetwarzanie danych

\section{INTRODUCTION}

Structural Health Monitoring (SHM) is an emerging field of technology that involves integration of sensors, data acquisition, data transmission and data processing systems for damage detection and localization purposes. It is based on many non-destructive damage detection and monitoring methods, which are continuously developed today. An appropriate SHM system installed on a tested object allows for it's continuous monitoring and delivers important information about any changes within the structure, which can lead to object damage and all it's consequences (including serious injuries). Depending on the method used in the particular SHM system, the hardware used for it's implementation usually contains appropriate set of elements. For vibration based methods a group of sensors and actuators integrated with tested object is required. Also some additional modules like power amplifiers, signal acquisition and data processing system are necessary. Of course those special data acquisition and data processing systems, which are necessary for SHM system to operate, can be implemented using different technologies available today. In order to build such system, designers have to consider many aspects. First of all, the designed system should be as easy to operate by prospective user as possible. Of course, each part of the system, like sig- nal generator and power amplifier, which together form signal for actuators, as well as signal acquisition system can be designed with the use of separate general purpose systems. However, these systems are often very expensive and do not fit target application in the sufficient way, especially in terms of integration stage. Another important factor are physical dimensions. Designed system has to be small enough in order to be integrated with tested object or to be mounted it on test stand. Size constraints and power consumption are those factors, which limit device portability. All those requirements make dedicated hardware solutions more attractive for end user than other ones.

Additionally, if designers choose to use programmable logic technology as a part of their systems, their final product may exhibit some additional features like easy hardware (and software) reprogrammability (flexibility). This allows for making changes in all those hardware system modules which are implemented in programmable logic devices. Thanks to this feature, it will be possible to accommodate the existing device, which was designed to fulfill a particular application requirements, to other slightly different application at little or even no additional cost. This feature is also very useful especially in the early stage of system development when some unpredictable circumstances forces the designer to make significant changes in system logic structure.

* AGH University of Science and Technology, Faculty of Mechanical Engineering and Robotics, Department of Robotics and Mechatronics, al. A. Mickiewicza 30, 30-059 Krakow, Poland; tbarszcz@agh.edu.pl; mendrok@agh.edu.pl; wojtektm@poczta.fm 


\section{CASE STUDY I}

As a first example, a system designed for damage detection in structures like aluminium plate will be presented. This system is based on nonlinear vibro-acoustic modulation phenomena which is present in damaged structure signal response. The phenomena was carefully described in (Klepka et al. 2010, 2011, 2012). The method assumes two simultaneously introduced excitations: low - frequency (modal) excitation and high frequency ultrasonic wave. If an object of interest is undamaged then the spectrum of structure response contains only two frequency components, corresponding directly with both excitation signals. If the structure is damaged then frequency spectrum of signal response additionally exhibits sideband components, which are located around two main previously noticed components. The number of those sidebands and their amplitude are then analyzed and deliver information about current structure state.

In order to build SHM system based on the mentioned above phenomena, the authors decided to use mixed CPU / FPGA architecture shown in figure 1.

Figure 1 shows EC Electronics PAQ-G system's signal acquisition module logic structure.

As shown in figure 1, final device has a modular structure with FPGA device as core component and microcontroller as auxiliary device. This architecture exhibits large flexibility, as many processes related directly with system functionality are implemented in FPGA device, which may be freely reprogrammable in the final product.

From the technical point of view, the main challenge was that both low and high frequency excitation signals had to be sampled simultaneously, regardless of sampling frequency value. What is more, the measured structure response has also been measured at the same time and fully synchronously with both excitation signals.

This makes the whole process very time demanding, especially for sample frequencies as high as $2.5 \mathrm{Msps}$ and greater.
Additionally, if we assume that excitation signals are formed by $\mathrm{D} / \mathrm{A}$ converters from 8-bit data samples, and $\mathrm{A} / \mathrm{D}$ converter resolution is 16-bit, then we receive $10 \mathrm{MB} / \mathrm{s}$ data stream which must be processed without any interruptions (which are so common in microcontroller world). In order to met those requirements, dedicated data control module was implemented inside FPGA device.

As shown in the figure 2, each D/A and A/D converter is controlled independently by separate dedicated modules. These controllers feed D/A converters with data received from FIFO data buffers, which are in turn filled by main data controller (designed as Finite State Machine). At the same time, data received from A/D converter is stored in output FIFO buffer, which are in turn read by main controller.

The main controller task is as follows:

- to synchronize data converters with each other (with use of their controllers),

- to read appropriate area of external memory and send data to D/A controllers,

- to store A/D data in separate area of external memory,

- to send A/D data to CPU (and then to PC) after measurement.

PAQ-G system was designed especially for SHM systems which are based on non-linear vibro-acoustic modulation phenomena. However, it's architecture can easily be adopted to support guided - waves based SHM methods (Klepka and Ambroziński 2010). It's specification does not involve any additional signal processing inside the device - all data processing is performed within PC software. The device itself behaves as a simple acquisition system with all functionalities necessary to maintain full measure process (except signal analysis). However, it does not mean that integration of signal processing inside device hardware structure is not possible. The next example will show how it can be accomplished.

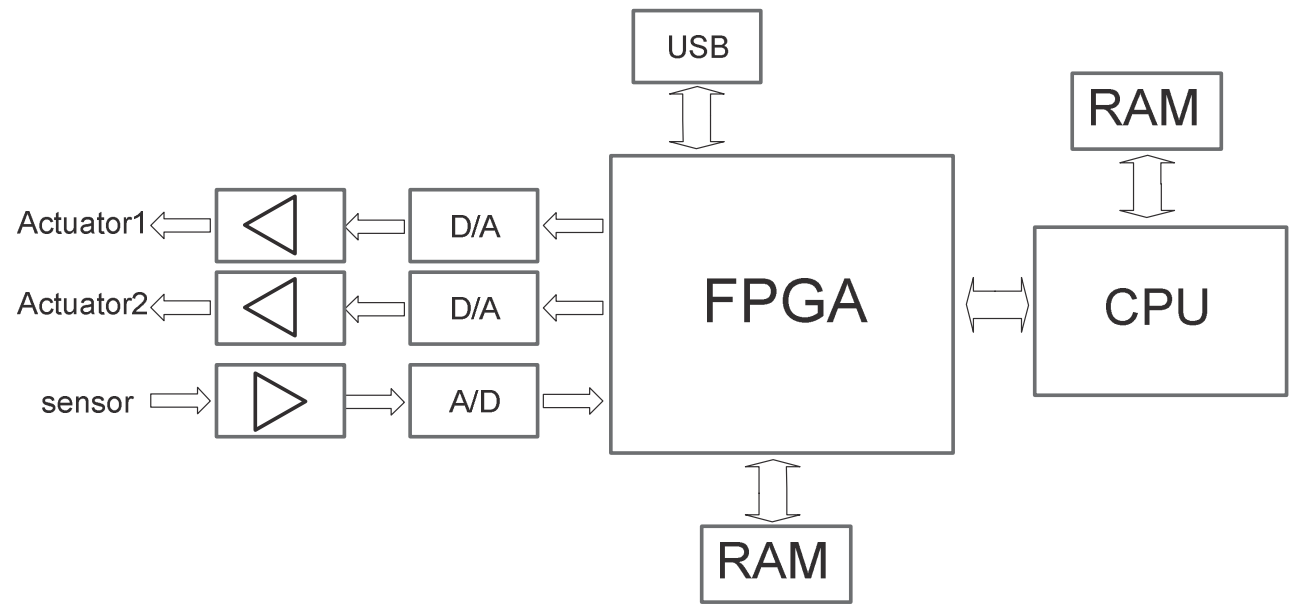

Fig. 1. PAQ-G system logic structure 


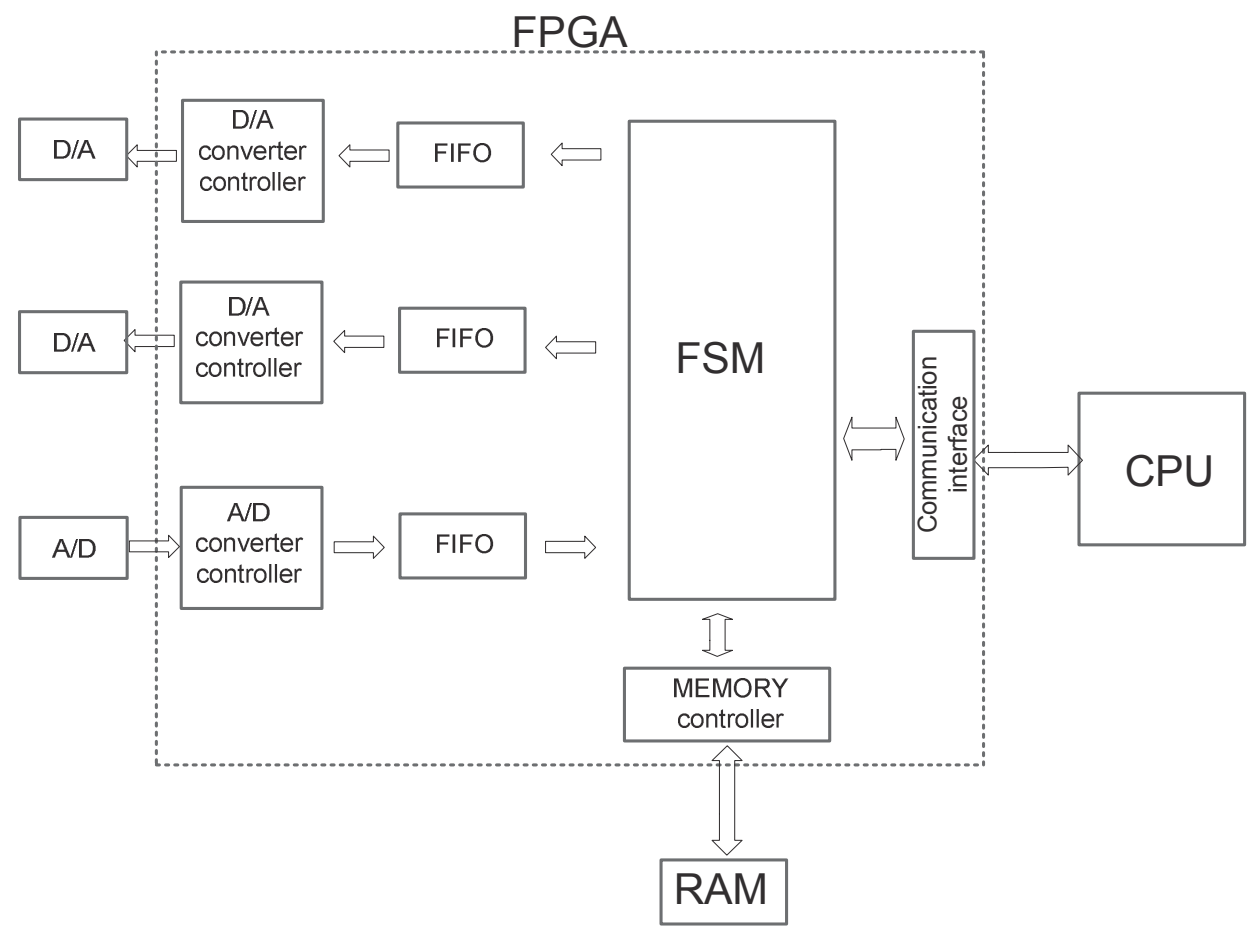

Fig. 2. PAQ-G FPGA internal logic structure

\section{CASE STUDY II}

As the next example, modal-filtering based SHM system internal logic structure will be presented. A modal filter is a tool that can be used to extract the modal coordinates of each individual mode from a system output (Mendrok et al. 2011). It decomposes the system responses into modal coordinates, and thus, on the output of the filter, the frequency response with only one peak, corresponding to the natural frequency to which the filter was tuned, can be obtained. When a local change occurs in the object - in stiffness or in mass (this usually happens when damage in the object arises), the filter stops working and on the output characteristic other peaks start to appear, corresponding to other, not perfectly filtered natural frequencies.

The damage detection method has already been described and tested numerically by the authors (Mendrok 2010). Carried out research shows that modal filter is an excellent indicator of damage detection.

It's main advantages are:

- low computational effort due to data reduction,

- ease of automation,

- low sensitivity to environmental changes.

In order to apply it in a real SHM system, dedicated measuring device has been designed and built (Mendrok et al. 2011, Mendrok and Maj 2012). It's logic structure is shown in figure 3.

As shown in figure 3 , the device logic structure is very similar to that described previously in figure 1 .
There are CPU and FPGA modules connected with each other and with some additional peripheral devices.

CPU module is included mainly for control purposes it implements user interface together with some peripheral devices like keyboard, LCD display and communication peripherals. FPGA module, however, contains all logic modules necessary for implementation of desired method. The device structure contains also $16 \mathrm{~A} / \mathrm{D}$ converters which move analog input signal delivered from vibration sensors into digital domain, and two high speed synchronous RAM modules needed for data buffering and data processing.

The FPGA internal logic structure is shown in figure 4.

FPGA goal is to provide synchronous signal acquisition from all 16 channels and maintain all functionality necessary for measurement process like triggering, configuration, over-condition detection and many others. The most significant difference (from structure shown in Fig. 2) is that FPGA also contains data processing module, so it is also responsible for desired algorithm implementation.

Thanks to that, CPU task is limited mainly to maintain control and auxiliary functions only. This is very important from the power consumption point of view, because CPU device does not need to be fast (and complicated), and therefore it consumes much less power. Of course FPGA device also consumes power, but it's power consumption can be precisely controlled during operation. Thanks to that the whole device can work fully independently in the diagnostic mode (without any PC connected to it), and it can be battery powered, which is very important especially in portable applications. 


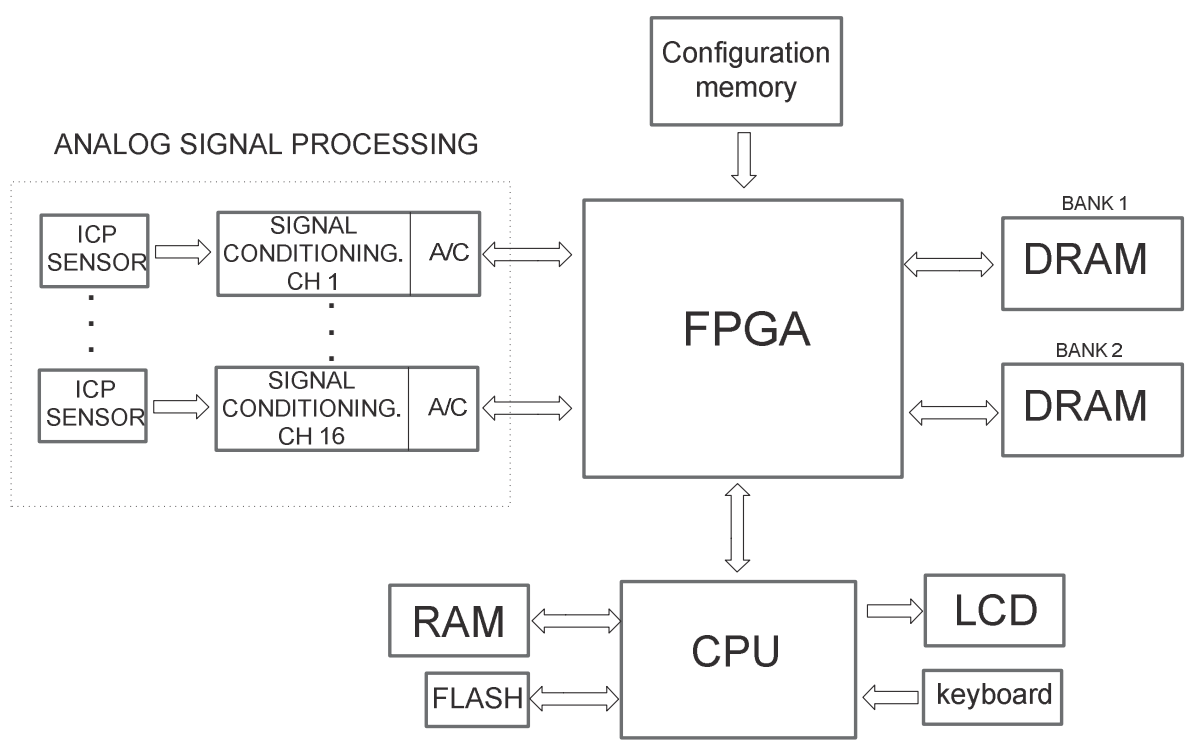

Fig. 3. MDFS system logic structure

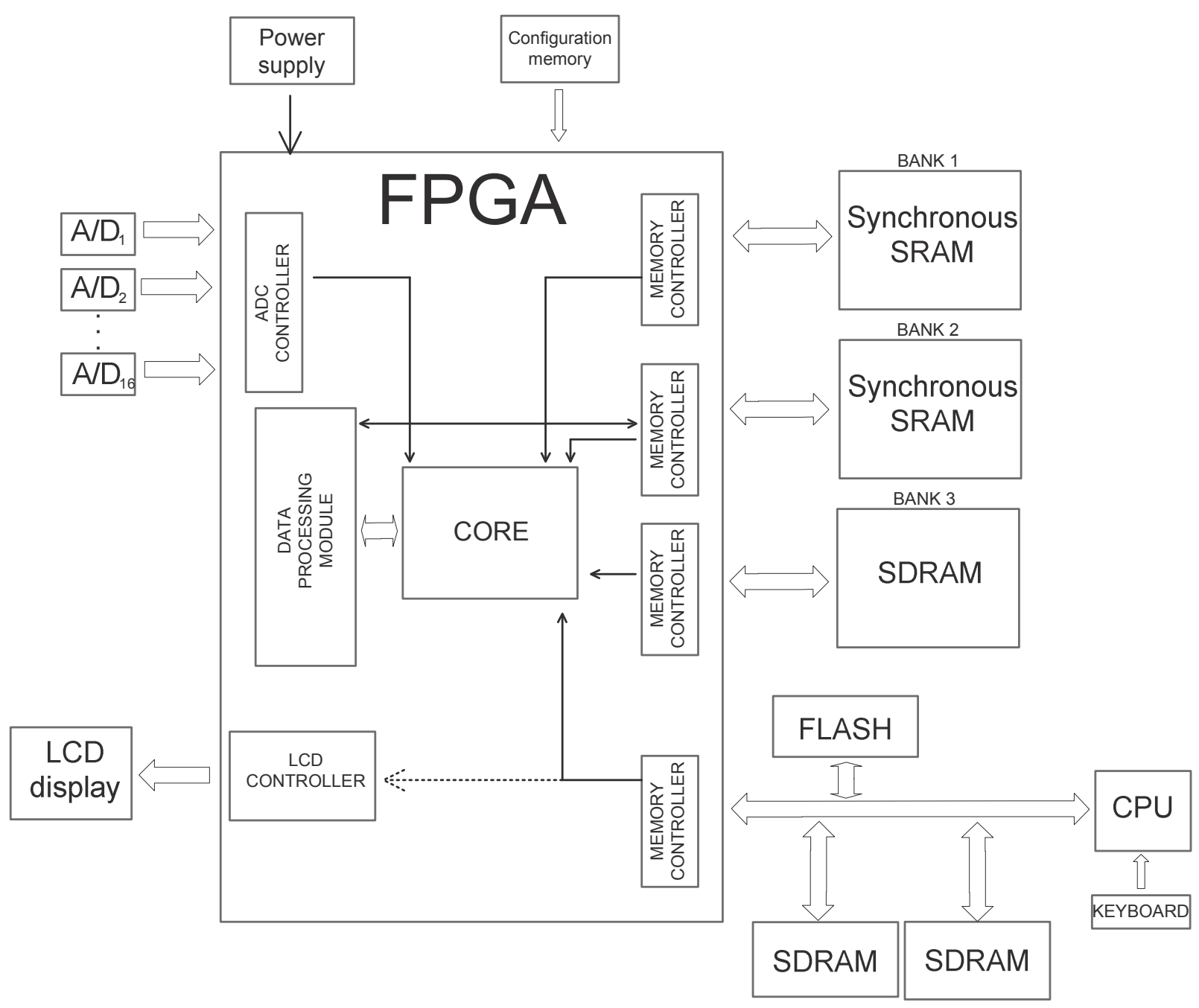

Fig. 4. MDFS system FPGA internal logic structure 


\section{CONCLUSIONS}

Programmable logic devices technology makes building and developing modern SHM systems much easier than before. Thanks to it some SHM methods, which were too complex to implement in autonomous portable devices, can be successfully implemented today. It is also possible to build much more flexible hardware platforms which supports wider range of SHM system applications. However, to take advantages of this technology, platform device have to carefully designed in order to meet future applications needs.

\section{References}

Ambrozinski Ł., Stępiński T., Uhl T., Ochoński J., Klepka A. 2012, Development of Lamb waves-based SHM systems. Key Engineering Materials, vol. 518, pp. 87-94.

Iwaniec J., Uhl T., Staszewski W.J., Klepka A. 2012, Detection of changes in cracked aluminium plate determinism by recurrence analysis. Nonlinear Dynamics, vol. 70, No. 1, pp. 125-140.

Jenal R., Staszewski W.J., Klepka A., Uhl T. 2011, Sensor location analysis for fatigue crack detection using nonlinear acoustics. [in:] Structural health monitoring 2011: condition-based maintenance and intelligent structures, proceedings of the 8th international workshop on Structural health monitoring, Stanford, September 13-15, 2011, (Ed. Fu-Kuo Chang), DEStech Publications Inc., Lancaster, pp. 1359-1367.

Klepka A., Ambroziński Ł. 2010, An application of guided waves for detection and localization of damages in plates. [in:] Wybrane zagadnienia analizy modalnej konstrukcji mechanicznych, Ed. Tadeusz
Uhl, Wydawnictwo Naukowe Instytutu Technologii Eksploatacji, pp. $175-180$

Klepka A., Jenal R.B., Staszewski W.J., Uhl T. 2011, Fatigue crack detection in metallic structures using nonlinear acoustics - comparative study of piezo-based excitation. [in:] 5th ECCOMAS thematic conference on Smart structures and materials SMART'11, Universität des Saarlandes, Saarbrücken, pp. 179-180.

Klepka A., Jenal R.B., Szwedo M., Staszewski W.J., Uhl T. 2010, Experimental analysis of vibro-acoustic modulations in nonlinear acoustics used for fatigue crack detection. [in:] Proceedings of the fifth European workshop Structural Health Monitoring, Eds. Fabio Casciati, Michele Giordano, DEStech Publications Inc., Pennsylvania, pp. 541-546 .

Klepka A., Staszewski W.J., Jenal R.B., Szwedo M., Iwaniec J., Uhl T. 2012, Nonlinear acoustics for fatigue crack detection - experimental investigations of vibro-acoustic wave modulations. Structural Health Monitoring, vol. 11, No. 2, pp. 197-211.

Klepka A., Staszewski W.J., Uhl T., Di Maio D., Scarpa F., Tee K.F. 2012, Impact damage detection in composite chiral sandwich panels. Key Engineering Materials, vol. 518, pp. 160-167.

Mendrok K. 2010, Simulation verification of damage detection algorithm. Diagnostyka, vol. 3, pp. 17-23.

Mendrok K., Maj W. 2012, Application of the modal filtration to the damage detection in truss structure. Diagnostyka, No. 4, pp. 31-37.

Mendrok K., Maj W., Uhl T. 2011, Laboratory tests of the SHM system based on modal filtration (in Polish). Diagnostyka, No. 1, pp. 13-20.

Mendrok K., Uhl T., Maj W.: Application of modal filtering for damage detection. [in:] CM 2011 / MFPT 2011: the eight international conference on Condition Monitoring and Machinery Failure Prevention Technologies, 20-22 June 2011, Cardiff, UK, The British Institute of Non- Destructive Testing, Northampton.

Mendrok K., Uhl T., Maj W., Paćko P. 2012, SHM system based on modal filtration. Key Engineering Materials, vol. 518, pp. 289-297. 